\title{
Article \\ Effects of Boiling and Roasting Treatments on the Content of Total Phenolics and Flavonoids and the Antioxidant Activity of Peanut (Arachis hypogaea L.) Pod Shells
}

\author{
Amro B. Hassan * (D), Salah A. Al Maiman, Ghedeir M. Alshammari, Mohammed A. Mohammed, \\ Haya F. Alhuthayli, Isam A. Mohamed Ahmed (D, Mohammed A. Alfawaz, Abu ElGasim A. Yagoub (D, Adil Fickak \\ and Magdi A. Osman
}

\begin{abstract}
Department of Food Science and Nutrition, Faculty of Food and Agricultural Sciences, King Saud University, P.O. Box 2460, Riyadh 11451, Saudi Arabia; smaiman@ksu.edu.sa (S.A.A.M.); aghedeir@ksu.edu.sa (G.M.A.); muhammed777a@gmail.com (M.A.M.); h.f.h4@hotmail.com (H.F.A.); iali@ksu.edu.sa (I.A.M.A.); malfawaz@ksu.edu.sa (M.A.A.); amohammed4@ksu.edu.sa (A.E.A.Y.); afickak@ksu.edu.sa (A.F.); magdios@ksu.edu.sa (M.A.O.)

* Correspondence: ahassan2ks.c@ksu.edu.sa; Tel.: +966-500-204-967
\end{abstract}

check for

updates

Citation: Hassan, A.B.; Maiman,

S.A.A.; Alshammari, G.M.;

Mohammed, M.A.; Alhuthayli, H.F.;

Ahmed, I.A.M.; Alfawaz, M.A.;

Yagoub, A.E.A.; Fickak, A.; Osman,

M.A. Effects of Boiling and Roasting

Treatments on the Content of Total

Phenolics and Flavonoids and the

Antioxidant Activity of Peanut

(Arachis hypogaea L.) Pod Shells.

Processes 2021, 9, 1542. https://

doi.org/10.3390/pr9091542

Academic Editors: Dariusz Dziki,

Anet Režek Jambrak and

Krystian Marszałek

Received: 3 August 2021

Accepted: 25 August 2021

Published: 30 August 2021

Publisher's Note: MDPI stays neutral with regard to jurisdictional claims in published maps and institutional affiliations.

Copyright: (c) 2021 by the authors. Licensee MDPI, Basel, Switzerland. This article is an open access article distributed under the terms and conditions of the Creative Commons Attribution (CC BY) license (https:/ / creativecommons.org/licenses/by/ $4.0 /)$.
Abstract: This study was conducted to investigate the effect of boiling and roasting treatments on the phenolic and flavonoid contents and antioxidant activity of pod shells of two Sudanese peanut cultivars, Sodari and Ghabiash. The samples were subjected to a boiling process $(1: 5 \mathrm{w} / \mathrm{v}$; $20 \mathrm{~g} / 100 \mathrm{~mL}$ ) at $100{ }^{\circ} \mathrm{C}$ for $45 \mathrm{~min}$ and a roasting treatment at $180{ }^{\circ} \mathrm{C}$ for $30 \mathrm{~min}$. Results revealed that both cultivars are rich in phenolic compounds with high antioxidant activity in their shell. The boiling and dry roasting treatments significantly $(p<0.05)$ enhanced the total phenolic content, total flavonoid content, and antioxidant activity of the peanut shell for both peanut cultivars. The shells of Ghabiash peanut cultivar exhibited higher bioactive properties than the shells of Sodari cultivar, in which these properties were highly improved by roasting and boiling treatments. In general, peanut shells can serve as an important underutilized by-product, particularly after roasting treatment, for potential applications in food formulations.

Keywords: peanut; shell; boiling; roasting; bioactive compounds

\section{Introduction}

Peanut (Arachis hypogaea L.), which belongs to the Leguminosae family, is one of the most produced commodities worldwide, grown primarily for its seed and oil worldwide [1] In general, peanut and peanut-based products are used as a magnificent source of food protein and bioactive compounds, with an appreciable content of antioxidants, flavonoids, and phenolic compounds, which are capable of preventing diseases such as cancer [2], coronary heart disease [3], and type-2 diabetes [4].

Recently, peanut shells have been used for several purposes. They are used as feedstock [5], food, fuel, filler in fertilizers [6], and bio-filter carriers [7]. They are also used in composting of wet materials, for waste-water treatment, plastic, and wardrobe [8].

Prabhakar et al. [9], reported that hemicellulose, cellulose and lignin are visibly present in peanut shells. Moreover, peanut shells have been recognized as a valuable source of protein along with other components such as fat, carbohydrate, sugars, and minerals [10]. As demonstrated by many scientists, peanut shells contain polyphenols, flavonoids, carotene, luteolin, isosaponaretin, and safely bioactive and functional compounds for human consumption [11-13].

It has been reported that the antioxidant and antimicrobial activities identified in a peanut shell can prevent insect pest attack [14]. Therefore, due to this accessible amount of natural antioxidants, the peanut shell has attracted the interest of several chemists 
and nutritionists $[15,16]$. Peanut shells showed incredible antioxidant potential with high amounts of phenolic and flavonoid compounds with high antioxidant activity [17]. Thermal treatments such as boiling and roasting are considered as an important step in the peanut processing industry to enhance the physicochemical characteristics and overall palatability of the end-user products of it [16]. A study conducted by Lee et al. [18] indicated that antioxidant activities of peanut shells were increased due to thermal treatments. Elsorady and Ali [19] reported that total phenols content and scavenging activity was higher in roasted peanut skin than unroasted peanut skin.

Peanut shells are a major industrial waste in peanut-producing countries. It was estimated that about 14 million tons of peanut shells are wasted worldwide $[20,21]$. Sudan contributes $14 \%$ of the world's total peanut production, reaching a yield of 2,884,000 metric tons of peanut pods in 2018, which was obtained from a harvested area of 3,066,000 ha [22]. Although there are no actual data in Sudan regarding the amount of wasted peanut shells either produced from oil production and peanut butter production or from direct consumption without shells, it is noted that the quantities of wasted shells increase annually. Hence, there exists a need to explore the potential of their use in food production. Therefore, this study was conducted to evaluate the phenolic and flavonoid contents and antioxidant activity of raw, boiled, and roasted peanut pod shells of two Sudanese peanut cultivars.

\section{Materials and Methods}

\subsection{Material and Chemicals}

Peanut (Arachis hypogaea L.) cultivars, specifically Sodari and Ghabiash, were obtained from the plant breeding division, Agricultural Research Corporation, Sudan. Peanut pods were washed, dried, and stored at room temperature before use. Phenolic standards (gallic acid and catechin) with purity $>97.5 \%$, Folin-Ciocalteu reagent, aluminum chloride, sodium nitrite, ascorbic acid, 2, 6-dichlorophenol indophenol dye, and 2,2-diphenyl-1picrylhydrazyl (DPPH) were purchased from Sigma-Aldrich Company Ltd. (Hamburg, Germany). All other chemicals used were of analytical grade.

\subsection{Boiling and Dry Roasting Processes}

The clean dried peanut pods of the two cultivars were divided into three portions; one portion was left untreated (raw). The other two portions were subjected to boiling and roasting treatments. Based on preliminary experiments, the boiling process was conducted in distilled water $(1: 5 w / v ; 20 \mathrm{~g} / 100 \mathrm{~mL})$ at $100{ }^{\circ} \mathrm{C}$ for $45 \mathrm{~min}$. The dry roasting process was performed in a preheated oven at $180^{\circ} \mathrm{C}$ for $30 \mathrm{~min}$. Approximately $500 \mathrm{~g}$ of whole peanut pods was spread on trays $(25 \times 25 \mathrm{~cm})$. Peanut shells of untreated (raw), boiled, and roasted pods were removed and then freeze-dried, ground to a fine powder, and stored at $4{ }^{\circ} \mathrm{C}$ until use.

\subsection{Crude Extract Preparation}

The crude extracts from the untreated and treated peanut seed shells were prepared by mixing a given weight of the sample with methanol at a solid-to-liquid ratio of 1:25 (w/v) in a beaker and wrapped with aluminum foil. The mixture was left at $25{ }^{\circ} \mathrm{C}$ overnight and then filtered. The residue was extracted twice with methanol. The filtrates were combined, dried in vacuum at $40{ }^{\circ} \mathrm{C}$, and stored for subsequent analyses.

\subsection{Determination of the Total Phenolic Content}

The total phenolic content of the untreated and treated samples was determined using the Folin-Ciocalteu reagent method [23]. An aliquot $(20 \mu \mathrm{L})$ of the dried sample extract solution, prepared in methanol $(1: 10, w / v)$, was mixed with $1.58 \mathrm{~mL}$ of distilled $\mathrm{H}_{2} \mathrm{O}$ and $100 \mu \mathrm{L}$ of Folin-Ciocalteu reagent. Then, $300 \mu \mathrm{L}$ of $\mathrm{Na}_{2} \mathrm{CO}_{3}$ solution (5\%) was added to the mixture and kept in the dark at room temperature $\left(25^{\circ} \mathrm{C}\right)$ for $2 \mathrm{~h}$. The absorbance of the mixture was read at $765 \mathrm{~nm}$. A blank was also prepared using distilled water instead of the sample, following the same procedure. A calibration curve was drawn using different 
concentrations of gallic acid versus the corresponding absorbance values $\left(R^{2}=0.9672\right)$. The results were expressed as milligrams of gallic acid equivalents per gram of sample (mg GAE/g sample, dry basis).

\subsection{Determination of the Total Flavonoid Content}

The total flavonoid content of the extracts from peanut shell samples was determined according to the method reported by Kim et al. [24]. A mixture of methanolic extract $(1 \mathrm{~mL}), 5 \% \mathrm{NaNO}_{2}$ solution $(300 \mu \mathrm{L})$, and $10 \%$ aluminum chloride $(300 \mu \mathrm{L})$ was incubated at $25{ }^{\circ} \mathrm{C}$ for $5 \mathrm{~min}$. Then, $1 \mathrm{~mol} / \mathrm{L}$ sodium hydroxide $(2 \mathrm{~mL})$ was added to the mixture. The volume of the mixture was made to be $10 \mathrm{~mL}$ using $\mathrm{H}_{2} \mathrm{O}$; it was then mixed thoroughly by vortexing, and the absorbance was recorded at $510 \mathrm{~nm}$. A catechin calibration curve was plotted $\left(R^{2}=0.974\right)$. The total flavonoid content of the sample was expressed as $\mathrm{mg}$ catechin equivalents (CE)/g sample on a dry basis.

\subsection{Antioxidant Activity of Peanut Shell}

\subsubsection{DPPH Scavenging Assay}

The DPPH radical scavenging ability of the extracts from the untreated and pretreated peanut shells was determined according to a previously described method [25]. Approximately I ml of $0.1 \mathrm{mM}$ DPPH-methanolic solution, $0.9 \mathrm{~mL}$ of $50 \mathrm{mM}$ Tris- $\mathrm{HCl}$ buffer ( $\mathrm{pH}$ 7.4), and $0.1 \mathrm{~mL}$ of the sample extracts or deionized $\mathrm{H}_{2} \mathrm{O}$, to serve as a control, were mixed and then incubated at room temperature for $30 \mathrm{~min}$. After incubation, the absorbance of the mixture was recorded at $517 \mathrm{~nm}$. The DPPH scavenging was calculated according to the following formula:

DPPH scavenging $(\%)=($ Absorbance Control-Absorbance sample $) /($ Absorbance control $) \times 100$

\subsubsection{Reducing Power}

The reducing power of the samples was determined according to the method described by Gulcin et al. [26]. Briefly, the extract $(1 \mathrm{~mL})$ was mixed with $2.5 \mathrm{~mL}$ of phosphate buffer $(0.2 \mathrm{M}, \mathrm{pH} 6.6)$, and $2.5 \mathrm{~mL}$ of $1 \%$ potassium ferricyanide was mixed and incubated at $50{ }^{\circ} \mathrm{C}$ for $20 \mathrm{~min}$, followed by the addition of $2.5 \mathrm{~mL}$ of $10 \%$ trichloroacetic acid and centrifugation at $1038 \times \mathrm{g}$ for $10 \mathrm{~min}$. Then, $2.5 \mathrm{~mL}$ of the supernatant was mixed with $2.5 \mathrm{~mL}$ of distilled $\mathrm{H}_{2} \mathrm{O}$ and $0.5 \mathrm{~mL}$ of $0.1 \%$ ferric chloride. The absorbance of the mixture was read at $700 \mathrm{~nm}$. Ascorbic acid was used as a reference standard, and results were expressed as ascorbic acid equivalents (AAE) per gram of sample.

\subsubsection{Hydrogen Peroxide Scavenging Assay}

The hydrogen peroxide scavenging ability of the untreated and treated samples was determined as described by Jayaprakasha et al. [27]. For this assay, $1 \mathrm{~mL}$ of the sample extract $(1 \mathrm{mg} / \mathrm{mL}$ ) was diluted in $3 \mathrm{~mL}$ of phosphate buffer ( $\mathrm{pH} 7.4)$, followed by the addition of $1 \mathrm{~mL}$ of $40 \mathrm{mM} \mathrm{H}_{2} \mathrm{O}_{2}$, prepared in the phosphate buffer ( $\mathrm{pH}$ 7.4). After incubation for $10 \mathrm{~min}$, the absorbance of the reaction mixture was measured at $230 \mathrm{~nm}$. The $\mathrm{H}_{2} \mathrm{O}_{2}$ scavenging ability of the sample was calculated as follows:

$\mathrm{H}_{2} \mathrm{O}_{2}$ scavenging $(\%)=($ Absorbance of the Control-Absorbance of the sample $) /($ Absorbance of the control $) \times 100$

\subsection{Statistical Analysis}

Data presented in figures are arithmetic mean values obtained from three replicated experiments. Data were statistically analyzed using the one-way analysis of variance. Significant differences between mean values $(p<0.05)$ were evaluated using the least significant difference (LSD) range test. Principal component analysis (PCA) and heatmap clustering analysis were conducted using the MULTBIPLOT software (Salamanca University, Spain) as described in the instruction manual. 


\section{Results and Discussion}

\subsection{Effect of Boiling and Roasting on the Total Phenolic Content of Peanut Shell}

The changes in the total phenolic contents of Sodari and Ghabiash pod shells due to boiling and roasting treatments are presented in Figure 1. It was observed that the processed peanut shell from both cultivars exhibited significantly $(p<0.05)$ higher total phenolic content (TPC) than that of the raw samples. However, raw Sodari and Ghabiash peanut shells had TPC values of 66.3 and $85.3 \mathrm{mg} \mathrm{GAE} / \mathrm{g}$, respectively, which increased to 75.42 and $81.73 \mathrm{mg} \mathrm{GAE} / \mathrm{g}$, and 101.83 and $85.3 \mathrm{mg} \mathrm{GAE} / \mathrm{g}$, respectively, after boiling and roasting. Similarly, several researchers have reportedly confirmed that thermal treatments can lead to an increase in the phenolic content of oilseeds. For instance, Kamalaja and Rajeswari [28] found that the roasting process significantly increased the TPC of peanut and sesame seeds. Elsorady and Ali [19] showed that the phenolic content of roasted peanut skin $(100.46 \pm 5.80 \mathrm{mg} / \mathrm{kg})$ was higher than that of unroasted peanut skin $(95.59 \pm 4.65 \mathrm{mg} / \mathrm{kg})$. In general, phenolic compounds are present in plant shells, hulls, peels, and other outer layers in free or bound forms [29].

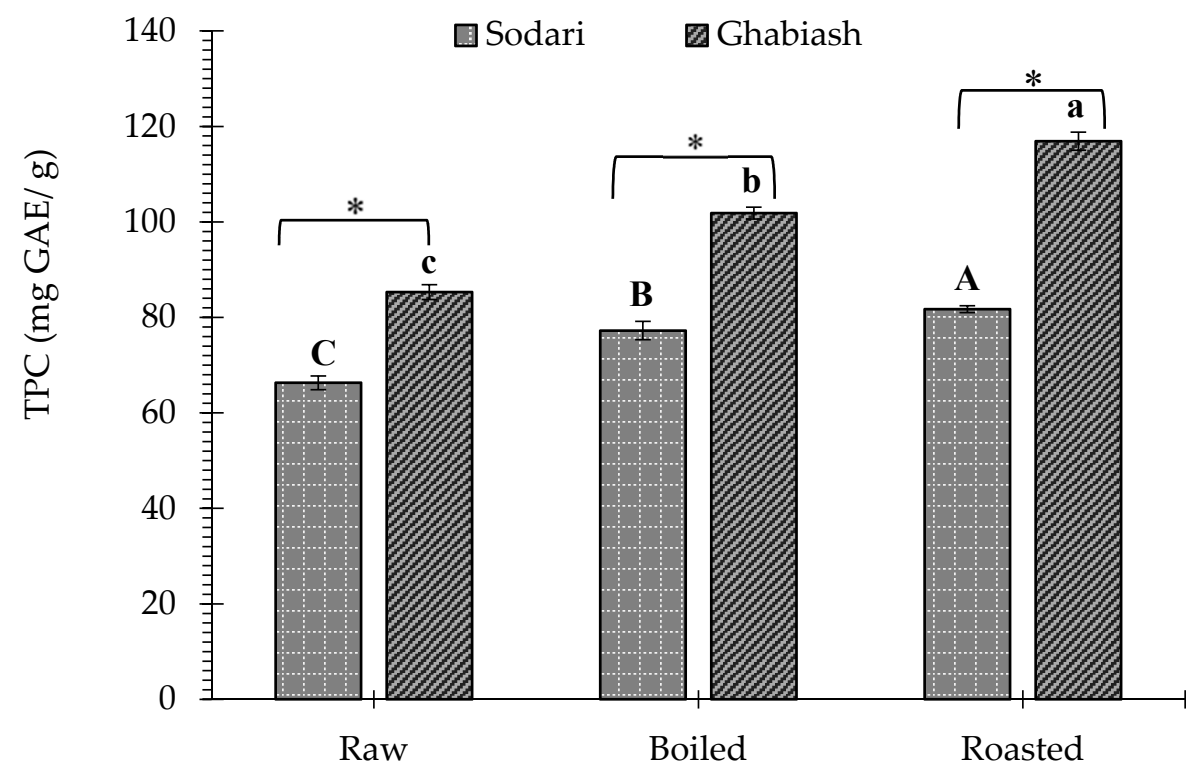

Figure 1. Effects of boiling and roasting on the total phenolic content (TPC) of peanut pod shells of Sodari and Ghabiash cultivars. Data represent mean \pm SD $(n=3)$. Values followed by the same letter are not significantly different $(p<0.05)$ as evaluated by LSD. Capital letters indicate significant differences between raw and processed samples of Sodari cultivars, whereas lower case letters indicate significant differences between raw and processed samples of Ghabiash cultivar. * shows the significant differences between means of cultivars, while ns shows the insignificant differences between means of cultivars in the raw and processed samples.

Therefore, heat treatment methods such as roasting and boiling can cause damage to the cell structure, thus increasing the extraction amount of phenolic compounds by solvents, and as a result, their concentrations are increased [30]. Moreover, the development of Maillard reaction products by heat treatments may contribute to the increase in the content of total phenolic compounds of roasted samples [31]. Additionally, the increases of TPC in peanut shell, particular the boiled and roasted ones, might be due to the breakdown of cellular constituents, which results in the release of free phenolic compounds and the formation of heat-induced and extractable phenolic compounds [32].

\subsection{Effect of Boiling and Roasting on the Total Flavonoid Content of Peanut Shell}

As shown in Figure 2, the peanut shells of Sodari and Ghabiash cultivars contain total flavonoid contents of 24.9 and $28.3 \mathrm{mg} \mathrm{CE} / \mathrm{g}$, respectively, which were increased significantly $(p<0.05)$ after boiling and roasting treatments. The increment in the TFC 
was found to be 82.7 and $133.9 \%$ after boiling treatment and 55.4 and $61.8 \%$ in the roasted sample for both Sodari and Ghabiash cultivars, respectively. However, the total flavonoid content (TFC) of the boiled shells of Sodari and Ghabiash cultivars (45.5 and $66.2 \mathrm{mg} \mathrm{CE} / \mathrm{g}$ ) was significantly $(p<0.05)$ higher than that of the roasted shells (38.7 and $45.8 \mathrm{mg} \mathrm{CE} / \mathrm{g}$ for Sodari and Ghabiash, respectively), consistent with the results reported earlier by Chukwumah et al. [33] and Kunyanga et al. [34]. They stated a significant increment in the flavonoid content in boiled and roasted peanuts compared to raw ones. Similarly, different roasting treatments applied to various seeds and grains have been reported to increase the TFC of the seeds and grains $[32,35,36]$.

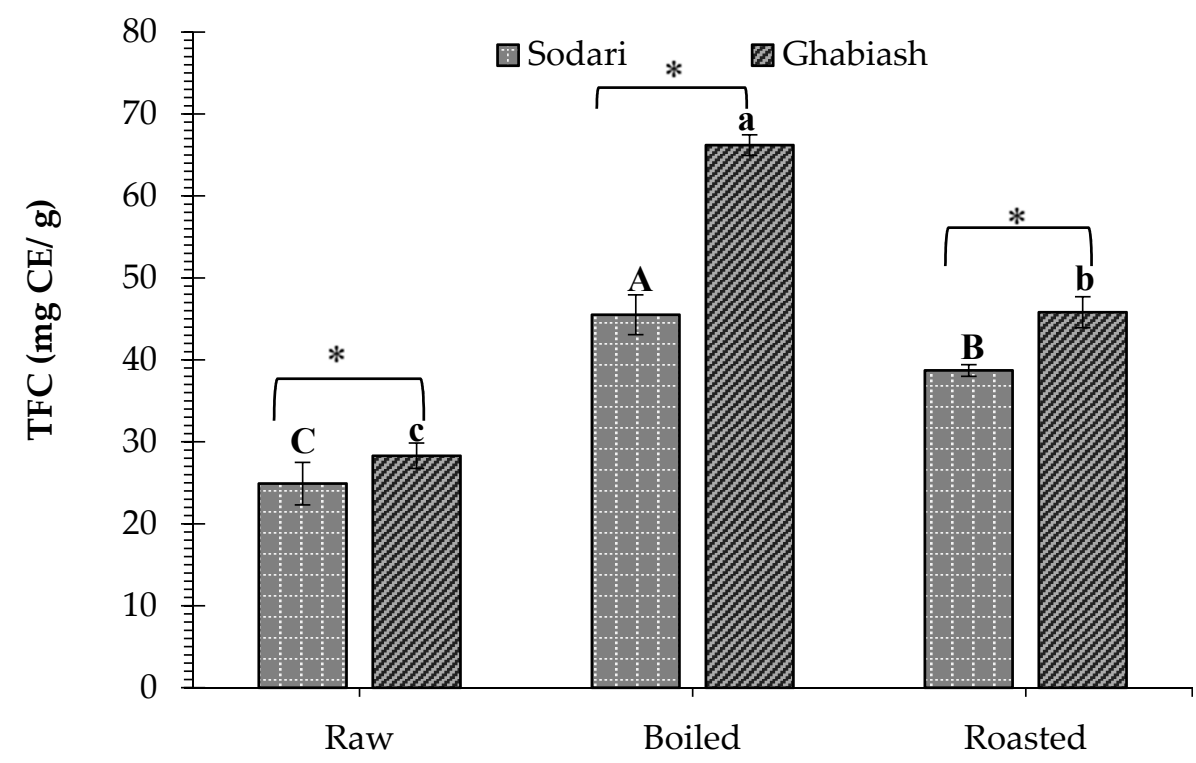

Figure 2. Effects of boiling and roasting on the total flavonoid content (TFC) of pod shells of peanut cultivars. Data represent mean $\pm \mathrm{SD}(n=3)$. Values followed by the same letter are not significantly different $(p<0.05)$ as evaluated by LSD. Capital letters indicate significant differences between raw and processed samples of Sodari cultivars, whereas lower case letters indicate significant differences between raw and processed samples of Ghabiash cultivar. * shows the significant differences between means of cultivars, while ns shows the insignificant differences between means of cultivars in the raw and processed samples.

The high flavonoid content found in peanut shells particularly after thermal treatment might be attributed to the presence of high amounts of secondary metabolite compounds in plant shells, hulls, peels, and other plant outer layers in free or bound forms [29], hence, heat treatment methods such as roasting and boiling may result in the release and increase the total flavonoids of the plants [30].

\subsection{Effect of Boiling and Roasting on the Antioxidant Activity of Peanut Shell}

Results of the effect of boiling and roasting processes on the antioxidant activity of the pod shells of Sodari and Ghabiash peanut cultivars are presented in Figures 3-5.

The DPPH scavenging activities of raw Sodari and Ghabiash shell samples were $80.9 \%$ and $82.5 \%$, respectively, which were significantly $(p<0.05)$ increased by $9.15 \%$ and $3.30 \%$, and $1.97 \%$ and $2.5 \%$ after roasting and boiling treatments, respectively. These results demonstrated that the DPPH scavenging activities of roasted Sodari and Ghabiash samples $(85.2 \%$ and $88.3 \%$, respectively) were significantly $(p<0.05)$ higher than those of the corresponding boiled samples. Moreover, the DPPH scavenging activity of roasted Sodari pod shells was superior to that of its counterpart, the Ghabiash sample. 


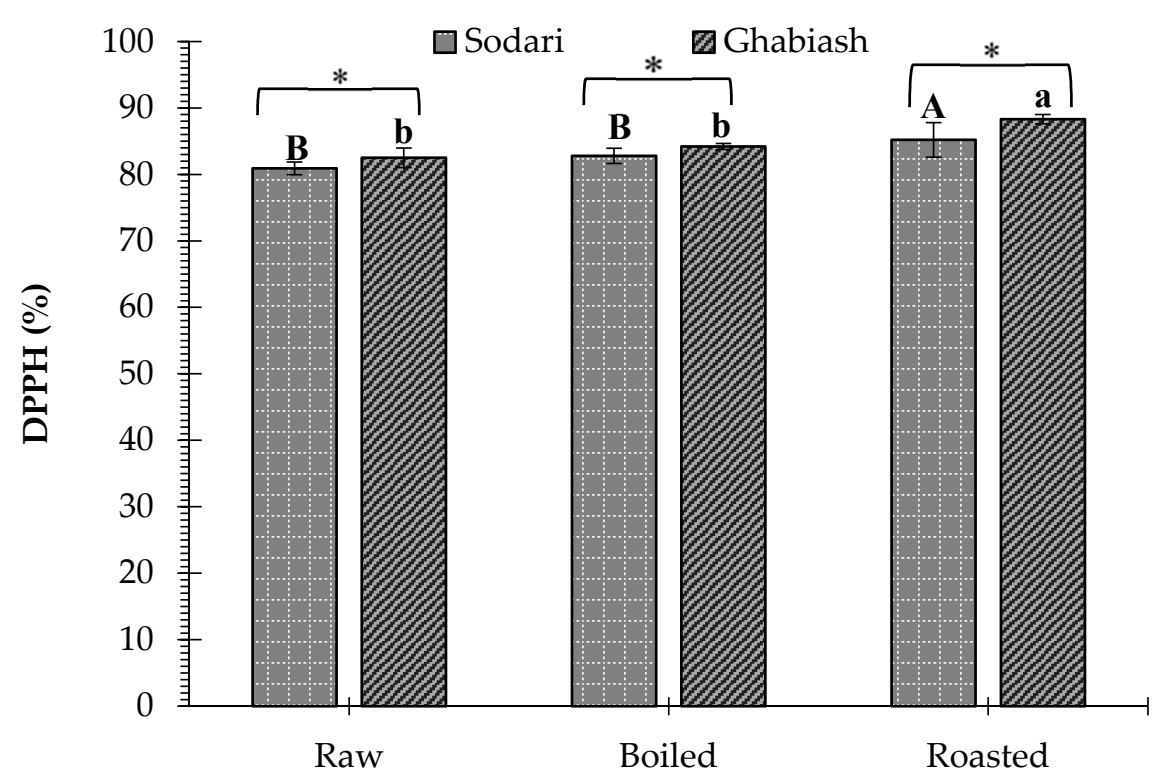

Figure 3. Effect of boiling and roasting on the DPPH scavenging activity (\%) of peanut cultivar shells. Data represent mean $\pm \mathrm{SD}(n=3)$. Values followed by the same letter are not significantly different $(p<0.05)$ as evaluated by LSD. Capital letters indicate significant differences between raw and processed samples of Sodari cultivars, whereas lower case letters indicate significant differences between raw and processed samples of Ghabiash cultivar. * shows the significant differences between means of cultivars, while ns shows the insignificant differences between means of cultivars in the raw and processed samples.

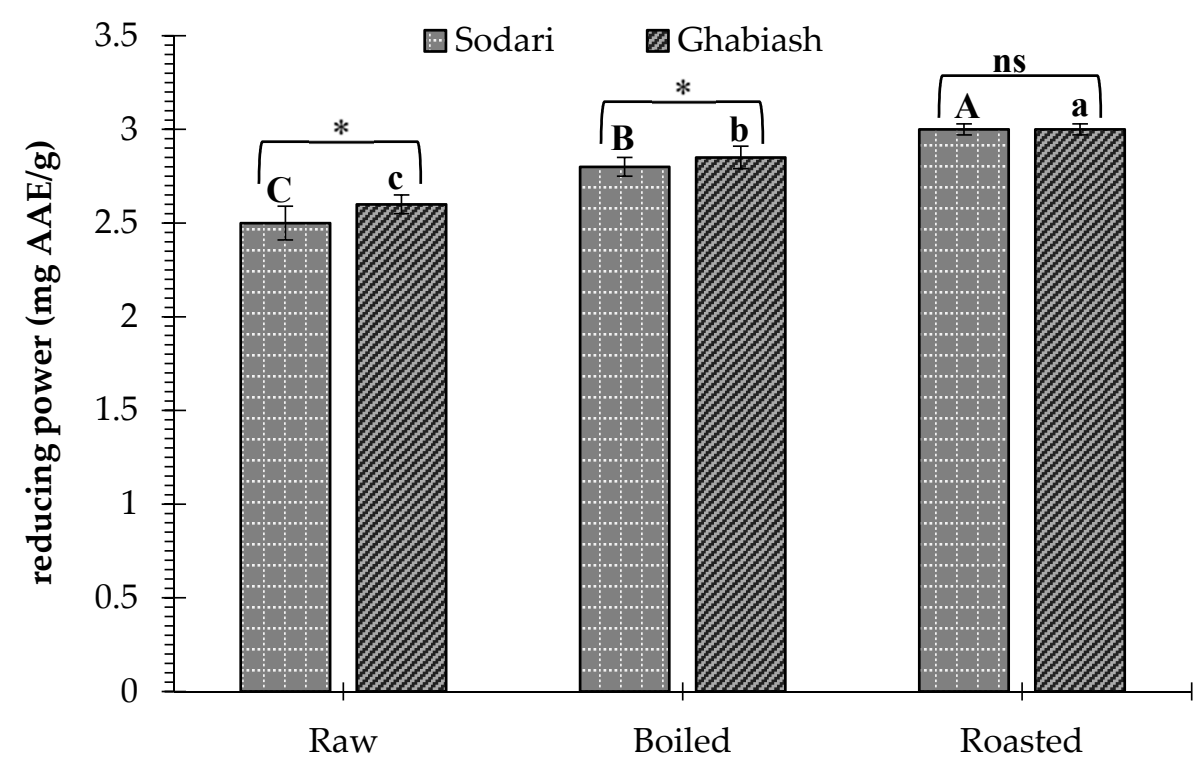

Figure 4. Effect of boiling and roasting on the reducing power of peanut cultivar shell. Data represent mean $\pm \mathrm{SD}(n=3)$. Values followed by the same letter are not significantly different $(p<0.05)$ as evaluated by LSD. Capital letters indicate significant differences between raw and processed samples of Sodari cultivars, whereas lower case letters indicate significant differences between raw and processed samples of Ghabiash cultivar. * shows the significant differences between means of cultivars, while ns shows the insignificant differences between means of cultivars in the raw and processed samples. 


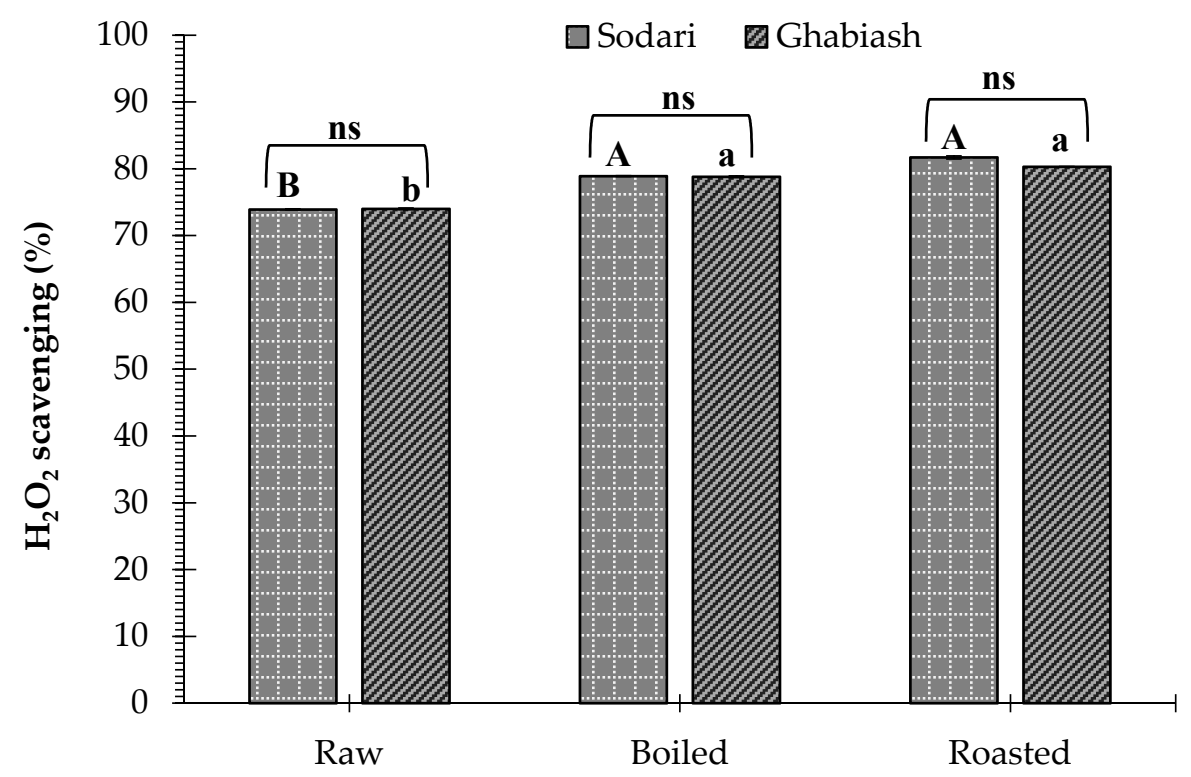

Figure 5. Hydrogen peroxide $\left(\mathrm{H}_{2} \mathrm{O}_{2}\right)$ scavenging ability of boiled and roasted peanut cultivar shells. Data represent mean \pm SD $(n=3)$. Values followed by the same letter are not significantly different $(p<0.05)$ as evaluated by LSD. Capital letters indicate significant differences between raw and processed samples of Sodari cultivars, whereas lower case letters indicate significant differences between raw and processed samples of Ghabiash cultivar. * shows the significant differences between means of cultivars, while ns shows the insignificant differences between means of cultivars in the raw and processed samples.

It is well known that the DPPH assay is one of the most accurate, sensitive, and widely used methods for characterizing the antioxidant capacity of food products [37]. The high ability of the peanut shells to scavenge DPPH free radicals might be due to the presence of different antioxidant compounds [15]. According to Fidrianny et al. [38], phenolic compounds of the shells of legume crops, including peanut, are the major contributor for the DPPH radical scavenging capacities. A study conducted on peanut shells of six Korean cultivars showed that the DPPH radical scavenging activity of peanut shells significantly varied, with values ranging from $61.9 \%$ to $87.6 \%$ [17]. Thermal food treatments such as boiling and roasting can cause the formation of Maillard reaction products, especially melanoidins, which possess the ability to scavenge oxygen radicals or chelate metals. Therefore, heat treatment increases the antioxidant capacity of the peanut. Elsorady and Ali [19] found that roasted peanut skins extracts exhibited higher DPPH scavenging activity than unroasted peanut skins. It has also been reported that roasting the flour of the whole peanut kernel for $10-50 \mathrm{~min}$ resulted in good scavenging activity $86.96 \%-88.61 \%$ compared to that of the unroasted sample $75.15 \%$ [16]. Results of the present study were in good agreement with the previously reported findings by [39-41].

The method of assessing the reducing power ability is dependent on the reduction of ferric ions $\left(\mathrm{Fe}^{3+}\right)$ to ferrous ions $\left(\mathrm{Fe}^{2+}\right)$ by the antioxidant compounds present in the test sample. Substances possessing a reduction potential react with potassium ferricyanide to form potassium ferrocyanide, which further reacts with ferric chloride to form an intense Prussian blue complex. The amount of the complex formed is directly proportional to the reducing power of the test sample [42].

The reducing power of raw peanut shells (Figure 4) was 2.5 and $2.6 \mathrm{mg} \mathrm{AAE} / \mathrm{g}$ for Sodari and Ghabiash cultivars, respectively, which conformed to the reducing power of peanut shells, ranging from 2.87 to $3.14 \mathrm{mg}$ AAE/g reported earlier [17]. The reducing power of the pod shells of Sodari and Ghabiash peanut cultivars was significantly $(p<0.05)$ increased by $16.0 \%$ and $19.2 \%$, and $12.0 \%$ and $15.4 \%$, respectively, after roasting and boiling treatments, indicating a better iron-reducing ability of the processed Ghabiash samples than that of Sodari samples. 
The hydrogen peroxide $\left(\mathrm{H}_{2} \mathrm{O}_{2}\right)$ scavenging ability of the control sample showed a similar trend of changes due to processing as in the DPPH scavenging activity and reducing power. The $\mathrm{H}_{2} \mathrm{O}_{2}$ scavenging activity of processed peanut shells of Sodari and Ghabiash cultivars was significantly $(p<0.05)$ higher than that of raw samples (Figure 3). However, the $\mathrm{H}_{2} \mathrm{O}_{2}$ scavenging activities of Sodari and Ghabiash peanut shells were $73.9 \%$ and $74.0 \%$, respectively, which were significantly $(p<0.05)$ increased by $11.0 \%$ and $8.5 \%$, and $6.9 \%$ and $6.5 \%$ after roasting and boiling treatments, respectively. The roasted and boiled Sodari samples exhibited better $\mathrm{H}_{2} \mathrm{O}_{2}$ scavenging ability than the Ghabiash samples. $\mathrm{H}_{2} \mathrm{O}_{2}$ is a biologically important, nonradical reactive oxygen species that can affect several cellular processes by generating hydroxyl radicals in cells [26]. The ability of the antioxidant activity of plant extracts to scavenge $\mathrm{H}_{2} \mathrm{O}_{2}$ can be attributed to their phenolic compounds, which can donate electrons to $\mathrm{H}_{2} \mathrm{O}_{2}$, thus neutralizing it to water. The results obtained in this study showed that the peanut shell has an exceptionally higher $\mathrm{H}_{2} \mathrm{O}_{2}$ scavenging effect that can be enhanced by thermal treatments, which might be due to its phenolic compounds. Furthermore, our results regarding the effect of thermal treatments on the $\mathrm{H}_{2} \mathrm{O}_{2}$ scavenging ability of peanut shells were in good agreement with those reported earlier [43].

\subsection{Principle Component Analysis (PCA)}

The PCA was conducted to explore the interactive impacts of peanut cultivar and treatment on the bioactive properties of peanut shells. The HJ-biplot shows that the first principal component $(\mathrm{PC} 1,77.75 \%)$ contributed more to the total variability $(89.41 \%)$ of the plotted components than the second component, PC2, 11.66\% (Figure 6A). The cosine of the acute angle between TPC and DPPH indicated strong positive correlations between them $(\mathrm{R}=0.885 ; p<0.05)$, which in turn suggested that the TPC contributed to the evaluated DPPH radical scavenging activity [44]. Similarly, the cosine of the acute angle between TFC and $\mathrm{RP}(\mathrm{R}=0.845 ; p<0.05)$ and $\mathrm{H}_{2} \mathrm{O}_{2}$ assays indicated positive correlations among them and the contribution of TFC to the evaluated activity using these methods. Interestingly, the control samples of both cultivars did not contribute to the bioactive properties of the samples. However, thermal treatments enhanced the antioxidant activity and total phenolic and total flavonoid contents of the peanuts shells in a cultivar-dependent manner. The maximum bioactive properties were observed in the Ghabiash cultivar subjected to thermal treatment compared to those in the Sodari cultivar. In Ghabiash cultivar, the shell samples subjected to roasting treatment had the highest TPC and DPPH radical scavenging activity, whereas those subjected to boiling treatment exhibited the highest TFC, $\mathrm{H}_{2} \mathrm{O}_{2}$, and RP values. The shells of Ghabiash peanut cultivar exhibited higher antioxidant activity, TPC, and TFC than those of Sodari cultivar, and these bioactive properties were significantly enhanced by thermal treatments (boiling and roasting).

To evaluate the contribution of peanut cultivars and thermal treatments to the examined bioactive property traits in depth, a heatmap cluster was constructed (Figure 6B). The horizontal axis groups are the samples based on the thermal process rather than the peanut cultivar. The variation in color and color intensity indicates the variability of data values, with the red color indicating the maximum values and the green color indicating the minimum values [44]. Interestingly, three separate horizontal branches were clearly formed, showing the impact of thermal treatments on the bioactive properties of the peanut shell samples, wherein the upper cluster composed of roasted and boiled samples of Ghabiash cultivar with high values for all the evaluated traits. The middle cluster contained the roasted and boiled shell samples of Sodari cultivar, in which roasting treatment outscored boiling treatment for all traits. The lower cluster shows the lowest values recorded in the control shell samples of both cultivars. In general, roasting treatment outscored boiling in improving the bioactive properties of peanut shell samples, with the maximum improvement being observed in Ghabiash cultivar. Similarly, a recent study showed that roasting treatment improved the bioactive properties of peanut oil [45]. In conclusion, the shells of Ghabiash cultivar could be recommended as a suitable source of bioactive compounds, whose properties could be improved by roasting and boiling treatments. 

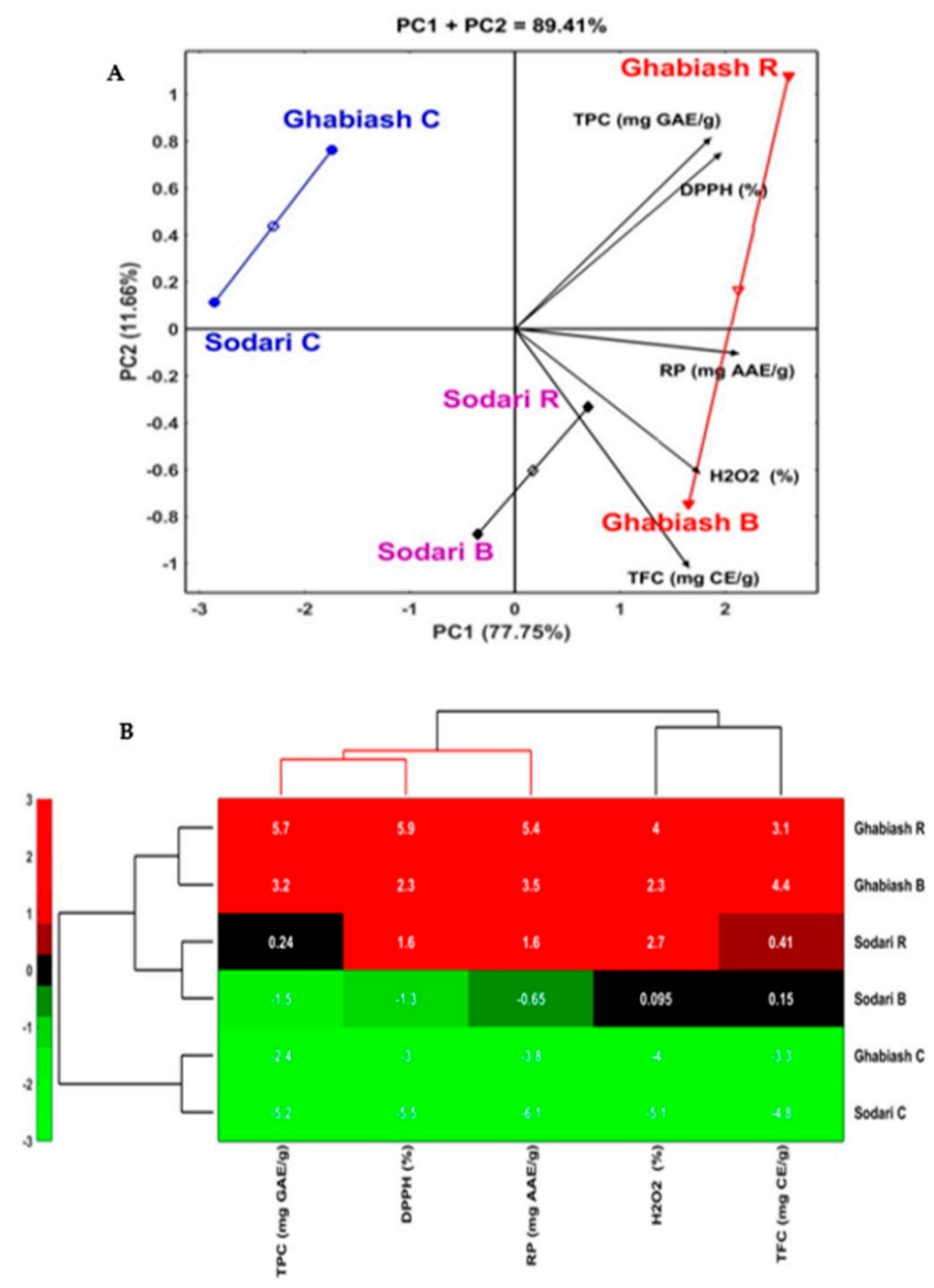

Figure 6. HJ-biplot based on the principal component analysis (A) and heatmap (B) of peanut shells of Sodari and Ghabiash cultivars as affected by roasting and boiling treatments.

\section{Conclusions}

This study demonstrated that boiling and roasting treatments resulted in changes in the chemical composition and antioxidant activity of the pod shells of Sodari and Ghabiash peanut cultivars. Boiling and roasting increased the total phenolic and flavonoid contents and antioxidant activity of the pod shells of the cultivars. The DPPH radical and $\mathrm{H}_{2} \mathrm{O}_{2}$ scavenging ability and the reducing power ability of Sodari and Ghabiash pod shells were higher in roasted samples than in boiled samples. The DPPH radical and $\mathrm{H}_{2} \mathrm{O}_{2}$ scavenging abilities of Sodari roasted sample were significantly higher than those of Ghabiash boiled samples; the opposite was true in terms of the reducing power activity. Peanut pod shell treatments, particularly roasting, could be a promising and valuable treatment method for improving the antioxidant activity of bioactive compounds in peanut shells. However, further studies concerning the structure and profiling of the phenolic and flavonoids compounds of the peanut shell are required. Hence, they can serve as an important underutilized by-product for potential applications in functional food formulations.

Author Contributions: A.B.H.: Methodology, data curation, funding acquisition, writing draft. I.A.M.A.: Data curation. A.F.: Writing—original draft preparation. M.A.M.: Data curation, visualization. H.F.A.: Data curation. G.M.A., S.A.A.M., A.E.A.Y., M.A.A., M.A.O.: Writing-reviewing and editing. All authors have read and agreed to the published version of the manuscript.

Funding: This project was funded by the Deanship at King Saud University through research group NO. RG-1441-497. 
Institutional Review Board Statement: Not applicable.

Informed Consent Statement: Not applicable.

Data Availability Statement: Data are contained within the article.

Acknowledgments: The authors extend their appreciation to the Deanship of Scientific Research at King Saud University for funding this work through research group NO. RG-1441-497. The authors thank the Deanship of Scientific Research and RSSU at King Saud University for their technical support.

Conflicts of Interest: The authors declare no conflict of interest.

\section{References}

1. Bertioli, D.J.; Seijo, G.; Freitas, F.O.; Valls, J.F.; Leal-Bertioli, S.C.; Moretzsohn, M.C. An overview of peanut and its wild relatives. Plant Genet. Res. 2011, 9, 134-149. [CrossRef]

2. Awad, A.B.; Fink, C.S. Peanuts as a source of B-sitosterol, a sterol with anticancer properties. Nutr. Cancer 2000, 130, 2127-2130. [CrossRef] [PubMed]

3. Kris-Etherton, P.M.; Hu, F.B.; Ros, E.; Sabaté, J. The role of tree nuts and peanuts in the prevention of coronary heart disease: Multiple potential mechanisms. J. Nutr. 2008, 138, 1746S-1751S. [CrossRef]

4. Jiang, R.; Manson, J.E.; Stampfer, M.J.; Liu, S.; Willett, W.C.; Hu, F.B. Nut and peanut butter consumption and risk of type 2 diabetes in women. JAMA 2002, 288, 2554-2560. [CrossRef] [PubMed]

5. De Camargo, A.C.; Vieira, T.M.F.d.S.; Regitano-D'Arce, M.A.B.; De Alencar, S.M.; Calori-Domingues, M.A.; Canniatti-Brazaca, S.G. Gamma radiation induced oxidation and tocopherols decrease in in-shell, peeled and blanched peanuts. Int. J. Mol. Sci. 2012, 13, 2827-2845. [CrossRef] [PubMed]

6. Rui-he, M. Study on comprehensive utilization of peanut hull. Modern Agric. Sci. Technol. 2010, 4.

7. Ramırez-López, E.; Corona-Hernández, J.; Dendooven, L.; Rangel, P.; Thalasso, F. Characterization of five agricultural by-products as potential biofilter carriers. Bioresour. Technol. 2003, 88, 259-263. [CrossRef]

8. Zaaba, N.F.; Ismail, H.; Jaafar, M. Effect of peanut shell powder content on the properties of recycled polypropylene (RPP)/peanut shell powder (PSP) composites. BioResources 2013, 8, 5826-5841. [CrossRef]

9. Prabhakar, M.; Shah, A.U.R.; Rao, K.C.; Song, J.-I. Mechanical and thermal properties of epoxy composites reinforced with waste peanut shell powder as a bio-filler. Fibers Polym. 2015, 16, 1119-1124. [CrossRef]

10. USDA. Full Report (All Nutrients): 45213163. In Shell Peanuts; 2017; UPC: 011161033875. Available online: https://ndb.nal.usda. gov / ndb / (accessed on 22 June 2017).

11. Rosales-Martínez, P.; Arellano-Cárdenas, S.; Dorantes-Álvarez, L.; García-Ochoa, F.; López-Cortez, M.d.S. Comparison between antioxidant activities of phenolic extracts from Mexican peanuts, peanuts skins, nuts and pistachios. J. Mex. Chem. Soc. 2014, 58, 185-193. [CrossRef]

12. Zhang, G.; Hu, M.; He, L.; Fu, P.; Wang, L.; Zhou, J. Optimization of microwave-assisted enzymatic extraction of polyphenols from waste peanut shells and evaluation of its antioxidant and antibacterial activities in vitro. Food Bioprod. Process. 2013, 91, 158-168. [CrossRef]

13. Yu, Y.; Sun, X.; Gao, F. Inhibitory effect of polyphenols extracts from peanut shells on the activity of pancreatic lipase in vitro. Asian J. Chem. 2014, 26, 3401. [CrossRef]

14. Wee, J.-H.; Park, K.-H. Isolation of 4-hydroxycinnamic acid, 3-methoxy-4-hydroxycinnamic acid, and 3, 4-dihydroxybenzoic acid with antioxidative and antimicrobial activity from peanut (Arachis hypogaea). Food Sci. Biotechnol. 2001, 10, 84-89.

15. Qiu, J.; Chen, L.; Zhu, Q.; Wang, D.; Wang, W.; Sun, X.; Liu, X.; Du, F. Screening natural antioxidants in peanut shell using DPPH-HPLC-DAD-TOF/MS methods. Food Chem. 2012, 135, 2366-2371. [CrossRef] [PubMed]

16. Win, M.M.; Abdul-Hamid, A.; Baharin, B.S.; Anwar, F.; Saari, N. Effects of roasting on phenolics composition and antioxidant activity of peanut (Arachis hypogaea L.) kernel flour. Eur. Food Res. Technol. 2011, 233, 599-608. [CrossRef]

17. Adhikari, B.; Dhungana, S.K.; Ali, M.W.; Adhikari, A.; Kim, I.-D.; Shin, D.-H. Antioxidant activities, polyphenol, flavonoid, and amino acid contents in peanut shell. J. Saudi Soc. Agric. Sci. 2019, 18, 437-442. [CrossRef]

18. Lee, S.-C.; Jeong, S.-M.; Kim, S.-Y.; Park, H.-R.; Nam, K.; Ahn, D. Effect of far-infrared radiation and heat treatment on the antioxidant activity of water extracts from peanut hulls. Food Chem. 2006, 94, 489-493. [CrossRef]

19. Elsorady, M.; Ali, S. Antioxidant activity of roasted and unroasted peanut skin extracts. Int. Food Res. J. 2018, $25,43-50$.

20. Radhakrishnan, R.; Pae, S.-B.; Lee, B.-K.; Baek, I.-Y. Evaluation of luteolin from shells of Korean peanut cultivars for industrial utilization. Afr. J. Biotechnol. 2013, 12, 4477-4480.

21. Gao, F.; Ye, H.; Yu, Y.; Zhang, T.; Deng, X. Lack of toxicological effect through mutagenicity test of polyphenol extracts from peanut shells. Food Chem. 2011, 129, 920-924. [CrossRef] [PubMed]

22. Food and Agriculture Organization of the United Nations Statistical Database (FAOSTAT). 2020. Available online: http://www. fao.org/faostat/en/\#data/QC/visualize (accessed on 16 July 2020).

23. Waterhouse, A.L. Determination of total phenolics. In Current Protocols in Food Analytical Chemistry; Wrolstad, R.E., Ed.; John Wiley and Sons: New York, NY, USA, 2001; pp. I1.1.1-I1.1.8. 
24. Kim, D.-O.; Jeong, S.W.; Lee, C.Y. Antioxidant capacity of phenolic phytochemicals from various cultivars of plums. Food Chem. 2003, 81, 321-326. [CrossRef]

25. Chang, S.-T.; Wu, J.-H.; Wang, S.-Y.; Kang, P.-L.; Yang, N.-S.; Shyur, L.-F. Antioxidant activity of extracts from Acacia confusa bark and heartwood. J. Agric. Food Chem. 2001, 49, 3420-3424. [CrossRef] [PubMed]

26. Gülçin, İ.; Oktay, M.; Küfrevioğlu, Ö.İ.; Aslan, A. Determination of antioxidant activity of lichen Cetraria islandica (L.) Ach. J. Ethnopharmacol. 2002, 79, 325-329. [CrossRef]

27. Jayaprakasha, G.K.; Rao, L.J.; Sakariah, K.K. Antioxidant activities of flavidin in different in vitro model systems. Bioorg. Med. Chem. 2004, 12, 5141-5146. [CrossRef]

28. Kamalaja, T.; Prashanthi, M.; Rajeswari, K. Evaluation of antioxidant activity and bioactive compounds on domestic cooking method. Int. J. Curr. Microbiol. App. Sci. 2018, 7, 4090-4097. [CrossRef]

29. Jeong, S.-M.; Kim, S.-Y.; Kim, D.-R.; Jo, S.-C.; Nam, K.; Ahn, D.; Lee, S.-C. Effect of heat treatment on the antioxidant activity of extracts from citrus peels. J. Agric. Food Chem. 2004, 52, 3389-3393. [CrossRef]

30. Zou, Y.; Yang, M.; Zhang, G.; He, H.; Yang, T. Antioxidant activities and phenolic compositions of wheat germ as affected by the roasting process. J. Am. Oil Chem. Soc. 2015, 92, 1303-1312. [CrossRef]

31. Dittrich, R.; El-Massry, F.; Kunz, K.; Rinaldi, F.; Peich, C.C.; Beckmann, M.W.; Pischetsrieder, M. Maillard reaction products inhibit oxidation of human low-density lipoproteins in vitro. J. Agric. Food Chem. 2003, 51, 3900-3904. [CrossRef] [PubMed]

32. Ahmed, I.A.M.; Al Juhaimi, F.Y.; Osman, M.A.; Al Maiman, S.A.; Hassan, A.B.; Alqah, H.A.; Babiker, E.E.; Ghafoor, K. Effect of oven roasting treatment on the antioxidant activity, phenolic compounds, fatty acids, minerals, and protein profile of Samh (Mesembryanthemum forsskalei Hochst) seeds. LWT 2020, 131, 109825. [CrossRef]

33. Chukwumah, Y.; Walker, L.; Vogler, B.; Verghese, M. Changes in the phytochemical composition and profile of raw, boiled, and roasted peanuts. J. Agric. Food Chem. 2007, 55, 9266-9273. [CrossRef] [PubMed]

34. Kunyanga, C.N.; Imungi, J.K.; Okoth, M.W.; Biesalski, H.K.; Vadivel, V. Flavonoid content in ethanolic extracts of selected raw and traditionally processed indigenous foods consumed by vulnerable groups of Kenya: Antioxidant and type II diabetes-related functional properties. Int. J. Food Sci. Nutr. 2011, 62, 465-473. [CrossRef] [PubMed]

35. Boateng, J.; Verghese, M.; Walker, L.; Ogutu, S. Effect of processing on antioxidant contents in selected dry beans (Phaseolus spp. L.). LWT 2008, 41, 1541-1547. [CrossRef]

36. Ee, K.; Agboola, S.; Rehman, A.; Zhao, J. Characterisation of phenolic components present in raw and roasted wattle (Acacia victoriae Bentham) seeds. Food Chem. 2011, 129, 816-821. [CrossRef]

37. Boligon, A.A.; Machado, M.M.; Athayde, M.L. Technical evaluation of antioxidant activity. Med. Chem. 2014, 4, 517-522. [CrossRef]

38. Fidrianny, I.; Puspitasari, N. Antioxidant activities, total flavonoid, phenolic, carotenoid of various shells extracts from four species of legumes. Asian J. Pharm. Clin. Res. 2014, 7, 42-46.

39. Carciochi, R.A.; Galván, D.; Alessandro, L.; Manrique, G.D. Effect of roasting conditions on the antioxidant compounds of quinoa seeds. Int. J. Food Sci. Technol. 2016, 51, 1018-1025. [CrossRef]

40. Wani, I.A.; Gani, A.; Tariq, A.; Sharma, P.; Masoodi, F.A.; Wani, H.M. Effect of roasting on physicochemical, functional and antioxidant properties of arrowhead (Sagittaria sagittifolia L.) flour. Food Chem. 2016, 197, 345-352. [CrossRef] [PubMed]

41. Jogihalli, P.; Singh, L.; Sharanagat, V.S. Effect of microwave roasting parameters on functional and antioxidant properties of chickpea (Cicer arietinum). LWT 2017, 79, 223-233. [CrossRef]

42. Pisoschi, A.M.; Negulescu, G.P. Methods for total antioxidant activity determination: A review. Biochem. Anal. Biochem. 2011, 1, 106. [CrossRef]

43. Yen, G.C.; Duh, P.D. Scavenging effect of methanolic extracts of peanut hulls on free-radical and active-oxygen species. J. Agric. Food Chem. 1994, 42, 629-632. [CrossRef]

44. Mutwali, N.I.; Mustafa, A.I.; Gorafi, Y.S.; Mohamed Ahmed, I.A. Effect of environment and genotypes on the physicochemical quality of the grains of newly developed wheat inbred lines. Food Sci. Nutr. 2016, 4, 508-520. [CrossRef] [PubMed]

45. Zhang, D.; Li, X.; Cao, Y.; Wang, C.; Xue, Y. Effect of roasting on the chemical components of peanut oil. LWT 2020, 125, 109249. [CrossRef] 